Hasanuddin Economics and Business Review 05:1 (2021) 8-12

\title{
Governing of Village Fund in South Sulawesi
}

\author{
Samirah Dunakhir ${ }^{\mathrm{a}, *}$, Mukhammad Idrus ${ }^{\mathrm{a}}$ \\ ${ }^{a}$ Faculty of Economics, Universitas Negeri Makassar
}

\begin{abstract}
This study aims to contribute to the development of a village fund management model in South Sulawesi. To achieve the research objectives, data collection was carried out by collecting secondary data and conducting follow-up interviews in sample villages in South Sulawesi. The analysis data that used was the descriptive qualitative analysis. The results showed that the stages in managing village funds in several villages in South Sulawesi Province had generally been carried out well. However, several obstacles are still faced by implementers in the village. Communication is one of them. Another factor that has the potential to become an obstacle in implementing the stages of village fund management is Competence. Based on the results of interviews with research informants, it was found that the backgrounds of village fund managers were mostly not by the fields that had to be handled. This in turn has an impact on the performance of the village fund managers.
\end{abstract}

Keywords: village fund, village fund management, village fund stages

\section{INTRODUCTION}

The village as a unit of government organization dealing directly with the community has a very strategic role, especially in the implementation of tasks in the field of public services. The village has autonomy, marked by the independence of the village in managing or managing its household without interference from the government or outside parties. One form of autonomy given to villages is the provision of Village Funds. Starting at the beginning of 2015 , villages will receive a new budget source, namely the Village Fund, which comes from the State Revenue and Expenditure Budget (APBN).

The implementation of village financial autonomy will be a strength for the village government to manage, organize and run their households. However, the burden of village responsibilities and obligations also increased. Village finances that can support optimal development require good management from the village government. It is hoped that good governance in the implementation and management of village finances can be realized based on the principles of governance, namely transparent, accountable, and participatory, and carried out in an orderly manner and with budget discipline.

Some previous research shows that there are still some villages in Indonesia, which do not fully implement the financial

*Author in correspondence,

Email address: samirah.dunakhir@unm.ac.id (Samirah Dunakhir)

ISSN: 2549-3221 (Print) 2549-323X (Online)

DOI: $10.26487 /$ hebr.v5i1.2734 management rules established village. Shuha (2018) argues that the stages of village fund management in Lubuk Alung District are not following Permendagri Number 113 of 2014 concerning Village Financial Management. The stage that is carried out is only at the planning stage, while the implementation, administration, reporting, and accountability stages are not yet under the intended Permendagri. Then the management of village funds in Lubuk Alung District is hampered by several obstacles, such as human resources, delays in reporting, changes to the Village Income and Expenditure Budget (APBDesa), weak internet networks, and a lack of public understanding. Meanwhile, several previous studies (Sintia (2016), Ringo (2017), and Miftahuddin (2018)), also found that there were some of the same obstacles in the process of managing village funds. Among them is the planning process that is not on time; delay in disbursement of funds from local governments to villages; village budget planning that is still not on target; lack of deliberation between management and the community to review the village expenditure budget so that it is felt that the current year's budget is still inaccurate; late reporting to the regent; the accountability report has not been published to the public; less than optimal guidance and supervision from local governments; as well as community understanding of Village Fund policies is still low.

The same thing happened in several villages in South $\mathrm{Su}-$ lawesi Province. Based on the results of pre-research through direct interviews with village treasurers in Dampang Village, Gantarang District, Bulukumba Regency, it is known that several obstacles in managing village funds are: there is a delay 
in transferring village funds from the center so that the village fund program in Dampang Village is also late; there is a program whose budget realization is greater than the previously budgeted plan; and a lack of community participation in the village program planning process. Meanwhile, Parinding Village, which is one of the villages in Baraka District, Enrekang Regency, also shows the same constraints in managing village funds. Based on the results of pre-research through observations in the village, it is known that: there are several programs whose budget realization is greater than the planned budget; there is a delay in transferring funds from the central government, which affects the delay in implementing village programs and the village treasurer who is often late in closing the books, therefore delivery to the village head is also late.

Starting from the above background, this study is intended to further examine the management of village funds in South Sulawesi Province and the factors that influence its implementation. Thus, the main problems in this study are: How is the management of village funds in South Sulawesi? What the limiting factor in the management of village funds in South Sulawesi?

\section{LITERATURE REVIEW}

Village finance is regulated in several regulations, including Regulation of the Minister of Home Affairs Number 37 of 2007 concerning Guidelines for Village Financial Management (Kementerian Dalam Negeri Republik Indonesia, 2007) and Law Number 6 of 2014 (Dewan Perwakilan Rakyat Republik Indonesia, 2014) in Article 71 Paragraph (1) concerning Villages. Based on these regulations, it can be stated that village finances are the rights and obligations of the village in implementing village government which can be valued in money or goods.

While the financial management of the village is also stipulated in the Regulation of the Minister of Home Affairs No. 113 of 2014 on Rural Financial Management (Kementerian Dalam Negeri Republik Indonesia, 2014). The regulation states that village financial management is all activities that include planning, implementation, administration, reporting, and village financial accountability.

Village Financial Planning Stages According to the Minister of Home Affairs Regulation Number 113 of 2014 stipulates that the Village Secretary prepares and submits a Draft Regulation Rural Area concerning APBDes based on the RKPDes of the year concerned to the Village Head. Furthermore, the draft that was delivered by the Head of Village to Village Consultative Body to be discussed and agreed upon at the latest in October of the current year. The mutually agreed draft is submitted by the Village Head to the Regent / Mayor through the Camat for evaluation and stipulation.

The stages of implementation are based on the Regulation of the Minister of Home Affairs of the Republic Number 113 of 2014 concerning Village Financial Management (Kementerian Dalam Negeri Republik Indonesia, 2014), which includes, among other things, the rules regarding village revenues and expenditures in the context of implementing village authority through a village treasury account and supported by valid documents and complete evidence. The village government is also prohibited from levies as village revenues other than those stipulated in village regulations.

Phase Administration on Minister Regulation Number 113 the Year 2014 Financial Management village set among others on the use of General Ledger Assistant Tax and Bank Book by Treasurer Village for the recording of all receipts and expenditures of the village. Village Treasurer is also required to account for all uses of funds through accountability reports to the chief.

The Reporting Stage in the Minister of Home Affairs Regulation Number 113 of 2014 concerning Village Financial Management, regulates the reporting mechanism, among others, that the Village Head submits the realization of the APBDes implementation to the Mayor in the form of first semester reports and year-end semester reports.

Finally, the Accountability Stages in the Ministerial Regulation No. 113 of 2014 concerning Village Financial Management, regulates the accountability mechanism for the management of the Village Revenue and Expenditure Budget (APBDes), including that the report on the realization and the accountability report on the realization of the APBDes implementation is informed to the public in writing and with information media easily accessible to the public. Stage's financial management of this village to be an indicator for village financial management variable.

The financial management of village funds is also expected to meet the principles of village financial management as stipulated in Kementerian Dalam Negeri Republik Indonesia (2014), namely transparent, accountable, participatory, and carried out in an orderly manner and budget discipline. The authority for village financial management as described in Kementerian Dalam Negeri Republik Indonesia (2014) is in the hands of the Village Head who is assisted by the Village Financial Management Technical Implementer (PTPKD).

\section{METHOD}

This research is a type of qualitative research that is descriptive research. The selection of qualitative research types in this study was carried out to better reveal events and facts by the research title, namely the analysis of financial management of village funds in South Sulawesi. Based on the topic of the problems raised, the variable that becomes the focus of this study is the Village Fund Financial Management in South Sulawesi.

This research is qualitative research, which is a descriptive research and tends to use analysis with a descriptive approach. With the consideration that in this study, the hypothesis was not tested using statistical methods. The variables in this study are village financial management with measurements seen from the stages which include planning, implementation, administration, reporting, and accountability, then the village apparatus involved includes the village head, village secretary, chief and officer, and finance chief.

The population in this study are documents and officials who support the financial management process of village funds 
in South Sulawesi. The sample in this study were documents and officials who supported the financial management process of village funds in several villages in South Sulawesi.

Considering limited research time and funds, this research will only be conducted in one or two villages in four districts in South Sulawesi, namely Parinding Village, Enrekang Regency, Dampang Village, Gantarang District, Bulukumba Regency, Sangkala Village, Kajang District, Bulukumba Regency, Lekopancing Village, Tanralili District, Regency Maros, and villages in Bontomanai District, Selayar Regency in 2018.

The sampling technique was purposive sampling. The selection of the four districts is based on regional representatives in South Sulawesi. Maros Regency is an area directly adjacent to the capital city of South Sulawesi Province, while Enrekang Regency is bordered by West Sulawesi Province. Bulukumba and Selayar Regencies represent the southern region of South Sulawesi Province.

\subsection{Data Collection}

The nature of this research is the engineering documentation and interview. The data in the study were collected using documentation through data sets and documents related to village funds in the sample villages. The interview technique used was unstructured interviews. According to Sugiyono (2016), an unstructured interview is an independent interview where the researcher does not use interview guidelines that have been systematically and completely structured for data collection. Interviews were conducted with village officials who were directly related to the object and research variables. Interviews were conducted to support the findings of previous documentation.

\subsection{Data Analysis}

The data analysis technique used in this research is descriptive analysis. Descriptive analysis is a way of formulating and interpreting existing data so that it provides a clear picture of the financial management of village funds. Descriptive analysis collects, compiles, analyzes data to obtain a true picture of the financial management of village funds with existing theories to provide complete information for solving the problems faced. Thus, this analysis technique is used to clearly describe the financial management of village funds in Parinding Village, Enrekang Regency, Dampang Village, Gantarang District, Bulukumba Regency, Lekopancing Village, Tanralili District, Maros Regency, Sangkala Village, Kajang District, Bulukumba Regency, and villages in Selayar Regency.

\section{FINDING AND ANALYSIS}

\subsection{Planning Stage}

The planning stage is the most important in the management of village funds because at this stage of $p$ Planning for over government revenues and expenditures the village for the budget year in respect of and should be budgeted in APBDesa. This stage of planning is considered as one of the supporters of good governance in village financial management. For this reason, the planning stage for village financial management must be by legislation.

Based on the results of research in several villages in South Sulawesi Province, it was found that the village fund managers in these villages had implemented a Village Fund Management Plan as outlined by the Permendagri. P Planning for the village fund in the village Dampang Bulukumba, for example, was carried out by preparing a draft regulation on APBDesa based RKPDesa village earlier, although there are still shortcomings in the administration of the proposed procedure that is not through the sub-district. The draft RKP has also been drafted and decided jointly through a Musrembangdes meeting, as happened in Sangkala Village, Bulukumba Regency. Business fund village has also made RPJMDesa as the basis for RKPDesa as happened in the village of Lekopancing, where $p$ is no phase Planning for the management of the Village Government Village Fund started with the creation of Rural Medium Term Development Plan (RPJMDesa). This RPJMDesa was created since the election of the head of Lekopancing Village. Furthermore, guided by the village medium-term development plan, the village government of Lekopancing prepared a Village Government Work Plan (RKPDesa) to identify and determine the Village Government work program for one year. Furthermore, after the determination of the RKPDesa, the Village government makes the APBDesa for the current year.

\subsection{Implementation Stage}

Implementation Stage The management of village funds is the administrative stage. Everything related to village funds at this stage is administered in an orderly manner, starting from the expenditure of funds for each activity based on village regulations, to the inflow and outflow of village funds which must go through a registered bank account. According to the Minister of Home Affairs Regulation Number 20 of 2018, it is explained that all Village revenues and expenditures in the context of implementing village authority are carried out through a cash account and there is valid evidence for every transaction.

Based on the results of research in several villages in South Sulawesi Province, it can be seen that village fund implementers have understood the stages in Village Fund Implementation. For example, in Desa Lekopancing, at this stage, the Village Government of Lekopancing creates a Village Cash Account, where this cash account functions to record Village Fund receipts and disbursements. To make cash withdrawals, the Lekopancing Village government assigned as executing budget activities prepares a Fund Usage Plan (RPD), Village Budget Plan, and a disbursement recommendation document signed by the Head of Tanralili Sub-district and then legalized by PMD. After the disbursement is carried out, all implementers in charge of managing the Village Fund must make an accountability report accompanied by valid evidence. This is of course under the relevant government regulations.

The implementation of village funds in Dampang Village also shows the same thing. Before doing activities, implementing activities in advance that he proposed budget has to be verified by the secretary of the village and passed by the village 
chief. Based on the Budget Plan, the activity implementer submits a Payment Request Letter to the Village Head. If the Payment Request Letter is approved, the Village Treasurer will make the payment. The payment is made by transfer or cash.

\subsection{Administration Stage}

According to the Regulation of the Minister of Home Affairs Number 20 of 2018, it is explained that financial administration is carried out by the financial officer who records every receipt and expense and is accountable for money through reports. Based on the research results, it can be seen that village fund implementers in several villages in South Sulawesi Province have carried out this Administration Stage well. This can be seen from the availability of record books and other bookkeeping requirements for managing village funds. The administration of village fund management in Lekopancing Village, for example, is carried out by the financial department, in this case, the treasurer of the Lekopancing village. Records and expenses are recorded in a general cash book which is reported in the form of an accountability report. Likewise in Dampang Village, the Village Treasurer records every income and expenditure and closes the books at the end of each month in an orderly manner. The Village Treasurer also produces a monthly accountability report which is submitted monthly to the Village Head. To record these revenues and expenditures, the Village Treasurer uses a general cash book, a tax auxiliary book, and a bank book.

\subsection{Reporting Stage}

Based on the Regulation of the Minister of Home Affairs Number 113 of 2014 concerning Village Financial Management, the village fund reporting mechanism involves the submission of the realization of the APBDes implementation by the Village Head to the Regent / Mayor in the form of first semester reports and year-end semester reports. This has been done by the implementers of village fund management in South Sulawesi Province.

In the reporting of village funds in Sangkala Village, for example, it was carried out by compiling a Semester I report made by the Village Secretary and approved by the Village Head which was carried out on July 1, 2019, and the final semester report for the 2019 fiscal year was carried out on December 31,2019 . In the process of reporting on the use of village funds for the village, the head is demanded to be on time, if it is too late then the Regent has the right to delay the next disbursement of funds. In its implementation, the village government of Sangkala reported the accountability report directly to the Regent of Bulukumba, but no evidence was found that reporting had been made against the Regent of Bulukumba.

\subsection{Accountability Stage}

Under Ministerial Regulation No. 113 of 2014 concerning Village Financial Management, the accountability mechanism for the management of the Village Revenue and Expenditure Budget (APBDes) involves submitting information to the public in writing and with information media that is easily accessible to the public, such as announcement boards, community radio, and the media. other information. This has been carried out by village fund managers in South Sulawesi Province. The accountability of village funds in Dampang Village, for example, is carried out by compiling an accountability report by the Village Secretary.

The accountability report was submitted to the Bulukumba Regent by the Head of Dampang Village through the Gantarang Sub-District Head in January 2019. However, no evidence was found that the accountability report was submitted to the Gantarang Sub-District Head. For the accountability report on the realization of the APBDesa implementation, the community is informed through billboards installed in front of the Dampang Village Office and mosques in Dampang Village. The Accountability Stage in Sangkala Village, Kajang District, Bulukumba Regency also shows that things are not much different. The accountability step in the village is carried out by making an accountability report on the realization of the APBDesa implementation which is informed to the community through billboards placed in front of the Sangkala village office.

In general, the stages in the management of village funds in several villages in South Sulawesi Province have been carried out well. However, several obstacles are still faced by implementers in the village. Communication is one of them. Communication can be considered as inhibiting factor affecting the Fund Management village. Communication is a very important thing in human life because communication is a process of conveying the intentions or messages of the speaker to others. So, if someone wants to say something, that person should communicate. However, the reality that occurs in the villages that are the object of research shows that communication is one of the inhibiting factors in implementing village fund management.

The public less able to communicate their views in the official forum that the village government had difficulty in determining the program that will be implemented. In Musrenbang forum Desa seen that the community enthusiastic enough to attend the forum. However, based on the results of the research shows that the public is less able to express the opinion of its public. $\mathrm{P}$ there when Musrenbang Village takes place, seen from the minutes of the meeting that the community is not very active.

However, based on the information from the Village Head, it seems that many people are not satisfied after the forum implementation. Seen a lot of people who at the time of execution of Musrenbang Village is not active in the forum, but outside the active community, a forum to talk about the program that will be implemented. According to the village head, this was caused by the culture of the people who were not used to communicating in formal forums so that most people did not dare to express their opinion. Speaking in public is one technique or the art of talking to be owned by the speakers and participants of the meeting that the forum Village Musrembang conducted by village government officials not only takes place in one direction as in the case and government officials Village has difficulty knowing people's desire.

Another factor that has the potential to become an obstacle in implementing the stages of village fund management is Competence. K Competency is the ability to execute or per- 
form a job according to their skills and knowledge. Based on the results of interviews with research informants, it was found that the backgrounds of village fund managers were mostly not under the fields that had to be handled. On average, village fund managers are still graduates from Senior High School (SMA), and only a small proportion are graduates from the appropriate universities. This in turn has an impact on the performance of the village fund managers. Some people feel that the village fund managers have not worked effectively because they have not been considered to have achieved the target to help the village economy so that the benefits have not been felt by the village community itself.

\section{CONCLUSION}

Based on research that has been carried out in several villages in South Sulawesi Province, the following conclusions can be drawn: The management of village funds in several villages in South Sulawesi Province is by the Minister of Home Affairs Regulation Number 113 of 2014 concerning Village Financial Management, especially in the implementation and administration stages, while the planning, reporting, and accountability stages are generally inappropriate, such as submitting reports. to the Head of the district before submitting it to the regent.

The management of village funds in South Sulawesi Province is still constrained by matters relating to human resources, such as communication skills and educational background. The suggestions and input that can be used as consideration for interested parties include the following:

1. The village government should be more careful in keeping important documents because some evidence is not found regarding the management of village funds at the planning, reporting, and accountability stages.
2. The village government should consider the support of human resources who are competent in their fields.

3. For further research, it is hoped that it can expand the research location in several places and add research variables to be studied so that it can compare with the test results previously found.

\section{References}

Dewan Perwakilan Rakyat Republik Indonesia, 2014. Undang-Undang Nomor 6 Tentang Desa.

URL: https : //www.dpr.go.id/dokjdih/document/uu/UU_2014_6. pdf

Kementerian Dalam Negeri Republik Indonesia, 2007. Peraturan Kementerian Dalam Negeri Nomor 37 Tahun 2007 Tentang Pedoman Pengelolaan Keuangan Desa.

URL: https://peraturan.bpk.go.id/Home/Details/126413/ permendagri-no-37-tahun-2007

Kementerian Dalam Negeri Republik Indonesia, 2014. Peraturan Menteri Nomor 113 Tahun 2014 Tentang Pengelolaan Keuangan Desa.

URL: https://peraturan.bpk.go.id/Home/Details/111736/ permendagri-no-113-tahun-2014

Miftahuddin, 2018. Akuntabilitas da Transparansi Pemerintah Desa terhadap Pengelolaan Dana Desa (Studi Kasus: Desa Panggungharjo Kecamatan Sewon Kabupaten Bantul).

Ringo, E. S., 2017. Pengelolaan Keuangan Desa di Desa Adi Jaya Kecamatan Terbanggi Besar Kabupaten Lampung Tengah. kripsi Universitas Lampung Bandar Lampung. Bandar Lampung.

Shuha, K., 2018. Analisis pengelolaan dana desa (studi kasus pada desa-desa selingkungan kecamatan lubuk alung kabupaten padang pariaman). Jurnal Akuntansi 6 (2).

URL: http://ejournal.unp.ac.id/students/index.php/akt/ article/view/3787

Sintia, K. D., 2016. Pelaksanaan Undang-Undang Nomor 6 Tahun 2014 Untuk Mewujudkan Akuntabilitas Pengelolaan Keuangan Desa (Studi Kasus di Desa Toyomerto Kecamatan Singosari Kabupaten Malang).

Sugiyono, 2016. Metode Penelitian Kuantitatif, Kualitatif, dan Kombinasi (Mixed Methods). Alfabeta, XIII. Bandung. 